УДК 78.071.1(477.83/.86):378.6:78(477.83-25)

DOI:

Іван Фрайт, кандидат педагогічних наук, доиент кафедри народних музичних інструментів та вокалу Дрогобицького державного педагогічного університету імені Івана Франка

Петро Турянський, дочент кафедри народних музичних інструментів та вокалу Дрогобищького державного педагогічного університету імені Івана Франка

\title{
ВНЕСОК ГАЛИЦЬКИХ КОМПОЗИТОРІВ У ЗАСНУВАННЯ 1903 РОКУ ВИЩОГО МУЗИЧНОГО ІНСТИТУТУ У ЛЬВОВІ
}

У статті виявлено внесок галицьькх композиторів у заснування 1903 року Вищуого музичного інституту у Львові. Встановлено, щуо Вищчии музичний інститут у Львові став першим украӥнським музичним закладом освіти Західної Украӥни, у якому цілеспрямовано проводилася робота з підготовки професійних співаків, педагогів, виконавців на різних музичних інструментах.

В організації изього закладу взяли участь майже усі галицькі композитори. Навколо нього гуртувалася і талановита галицьька молодь, кращуі представники якої гідно представляли українське музичне мистецтво.

Ключові слова: музичне мистецтво; музична освіта; національне виховання; педагогічна діяльність; музичні товариства.

Jim. 9.

Ivan Frait, Ph.D.(Pedagogy), Associate Professor of the Folk Musical Instruments and Vocals Department Drohobych Ivan Franko State Pedagogical University

Petro Turyanskiy, Associate Professor of the Folk Musical Instruments and Vocals Department Drohobych Ivan Franko State Pedagogical University

\section{THE CONTRIBUTION OF GALICIAN COMPOSERS TO THE FOUNDING OF THE HIGHER MUSIC INSTITUTE IN 1903 IN LVIV}

The article reveals the contribution of Galician composers to the founding of the Higher Music Institute in 1903 in Lviv. It is established that the Higher Music Institute in Lviv became the first Ukrainian music school in Western Ukraine, which purposefully worked on the training of professional singers, teachers, and performers on various musical instruments.

Almost all Galician composers of the second half of the 19th and the beginning of the 20th centuries took part in the organization of this educational institution. They were convinced that music education and upbringing should be carried out on a national basis. Through their musical and pedagogical activities, they awakened in the Ukrainian people the desire for musical education, knowledge, and the development of Ukrainian musical art.

In the 90s of the XIX century Galician composers were the founders of the Ukrainian musical societies "Boyan". The historical role of the "Boyans" was that by concentrating almost all the musical life of Western Ukraine, having an extensive system of branches in all major cities, founding libraries, museums, music schools, organizing holidays, competitions, concerts, they played the role of a modern philharmonic; and were of great importance for the revival and development of Ukrainian professional music.

Thanks to the activities of "Boyan" music societies, the best works of national song and treasures of Ukrainian music became available to the widest public of the region. The singing of "Boyans" caused the emergence of new Ukrainian talents. Under the auspices of these societies, the foundations were laid for the cultivation of Ukrainian vocal and instrumental music.

The "Boyans" Music Society had a decisive influence on the establishment of the Higher Music Institute in 1903 in Lviv, which became one of the leading institutions in Western Ukraine, where many Western Ukrainian composers continued and began their activities. Together with its branches, with the Music Society M. Lysenko Higher Music Institute promoted Ukrainian music among the population of Western Ukraine and played an important role in preserving the heritage of national culture. It is in him that a new type of professional composer begins to form, which later, becoming a teacher, will significantly expand the scope of music schooling.

Keywords: musical art; music education; national education; pedagogical activity; music societies.

П остановка проблеми. Для відновлення історичної правди та виховання підростаючого покоління важливе значення має об'єктивне висвітлення історичного минулого нашогонароду,його культурної спадщини. Від того, як молоде покоління сприйме історичну минувшину, які ідеї і традиції візьме для наслідування, залежить майбутнє нашої держави. 


\section{ВНЕСОК ГАЛИЦЬКИХ КОМПОЗИТОРІВ У ЗАСНУВАННЯ 1903 РОКУ ВИЩОГО МУЗИЧНОГО ІНСТИТУТУ У ЛЬВОВІ}

Музична культура Західної України є однією зі складових частин історії української культури. Період другої половини XIX - початку XX ст. становить цілу епоху в розвитку української музики. Вона характеризується загальним піднесенням національної духовності, становленням і зміцненням культури, зокрема музичної.

3 початком XX ст. західноукраїнські землі, зокрема, Східна Галичина, стали своєрідним П'ємонтом у створенні єдиної Української держави, були провісником національнокультурного відродження. Особливе місце у цьому процесі належить галицьким композиторам, які своєю діяльністю заклали підвалини вищої музичної освіти в регіоні. Будучи засновниками українських музичних товариств, вони сприяли появі нових талантів. Саме в цих осередках утверджувалися гуманістичні принципи і норми стосунків між людьми, побудовані на дружбі, взаємній підтримці та допомозі, а також українське музичне мистецтво як важливий чинник у вихованні молоді та дорослих.

Виникнення та діяльність українських музичних товариств в умовах Австро-Угорського та польського панування на західноукраїнських землях було закономірним наслідком національнокультурного відродження краю, яке бере свій початок з кінця XVIII ст. Музичні товариства як важливий виховний чинник стали складовою частиною і національно-визвольної боротьби, а також спричинилися до заснування у 1903 р. Вищого музичного інституту у Львові.

Аналіз останніх досліджень та публікацій. Перші друковані праці, в яких відображено процес формування вищої музичної освіти в Західній Україні, - це насамперед, наукові матеріали про діяльність галицьких композиторів другої половини XIX - початку XX ст., а також про історію заснування і розвитку українських музичних товариств в регіоні. Особливої уваги заслуговують періодичні видання другої половини XIX ст.: “Слово”, “Галичанин”, “Діло”, “Учитель”, “Зоря" та ін.

Питання, пов'язані з діяльністю музичних товариств, зокрема “Боян”, знайшли помітне місце і в науково-публіцистичних працях першої половини ХХ ст. (до 1939 р.). Інтерес становлять статті, написані А. Вахнянином, В. Витвицьким, М. Волошином, І. Гриневецьким, Ю. Кматою, І. Копачем, T. Кормошем, С. Людкевичем, I. Охромовичем та ін.

На особливу увагу заслуговує перший музичний український часопис Західної України “Ілюстрований музичний календар”. Саме в ньому вперше були опубліковані матеріали про діяльність “Львівського Бояна”, “Перемиського Бояна”, “Коломийського Бояна”, “Стрийського Бояна”, “Тернопільського Бояна”, “Снятинського Бояна”, “Станиславівського Бояна та ін.

В українській науці радянського періоду діяльність музичних товариств знайшла відображення у наукових працях М. Білинської, І. Гриневецького, М. Загайкевич, Я. Колодій, Л. Мазепи, С. Павлишин, Л. Ханик, у дисертаційних роботах Л. Мазепи, Л. Ханик у підручниках з історії української музики та іншій музикознавчій літературі.

Значно збагатилося вивчення проблеми за останні роки. У низці наукових праць 3 питань розвитку українського музичного мистецтва в Західній Україні знайшла своє відображення і проблема становлення та розвитку вищої музичної освіти в регіоні. На особливу увагу заслуговують публікації, підготовлені Л. Мазепою, Л. Кияновською, О. Осадцею, Р.Сов'яком, І. Фрайтом, М. Черепанином, Л. Ханик та ін.

Мета статті - виявити внесок галицьких композиторів у заснування Вищого музичного інституту 1903 р. у Львові.

Виклад основного матеріалу. Друга половина XIX - початок XX ст. в Західній Україні характеризується підвищенням активності наукових пошуків у розробці основ національного музичного виховання, прагненням композиторів внести свою лепту в розвиток української музично-педагогічної науки.

Якісно новий період у діяльності галицьких композиторів наступає з часу створення перших музичних товариств, що стають творчою лабораторією, в якій питання навчання і виховання набирають нових форм, наповнюються новим змістом. Цей період (1890-1903) став переломним у розвитку музичної освіти, а також зумовив появу нових композиторів, які, працюючи в навчальних закладах регіону, внесли свіжий струмінь у їх діяльність. Саме їм, поряд з іншими композиторами, належить заслуга заснування i праця у перших українських музичних товариствах.

Як засвідчують наукові матеріали, наприкінці XIX ст., крім питань мистецького навчання i виховання в початкових і середніх школах, галицькі композитори щораз частіше звертають увагу на створення вищого музичного закладу 3 українською мовою навчання. Аналіз їх музичнопросвітницької діяльності дає підстави стверджувати, що думка про його заснування виникала ще у 50-х рр. ХІХ ст. Якщо у 50-60-х рр. цієї проблеми торкалися М. Вербицький і 


\section{ВНЕСОК ГАЛИЦЬКИХ КОМПОЗИТОРІВ У ЗАСНУВАННЯ 1903 РОКУ ВИЩОГО МУЗИЧНОГО ІНСТИТУТУ У ЛЬВОВІ}

Й. Левицький, то наприкінці XIX - на початку XX ст. iї порушують С. Людкевич, А. Вахнянин, В. Матюк, М. Копко та інші композитори. Так, С. Людкевич у статті “Кілька слів про потребу заснування українсько-руської консерваторії у Львові” писав: "Ми мусимо чим скорше створити у Львові такі музичні установи, що виробляли б нам гарний музичний матеріал на свою музичну культуру. В першу чергу такою установою мусить стати не що інше, як українсько-руська музична консерваторія, себто школа, що взяла б собі завдання і програму виробляти наші не раз великі таланти на фахових музикантів і артистів" $[5,1]$.

У заснуванні цього закладу активну участь взяли майже всі галицькі композитори. Зібравшись у червні 1901 р. на з’їзд “Боянів”, вони вирішили об'єднати всі музичні товариства в єдиний “Союз співацьких і музичних товариств” $[9,2]$. Однак реалізувати цю ідею вдалося аж в червні 1903 р., бо саме в цьому році львівське воєводство наказом № 53080 від 2 травня зареєструвало статут “Союзу співацьких і музичних товариств".

Зібравшись 15/28 червня в приміщенні “Руської Бесіди" на перші загальні збори, члени новозаснованого товариства прийняли рішення “зробити крок для зміни статуту в тому напрямку, щоб “Союз” мав право заснувати консерваторію музичну” [4, 3]. Крім того, “Союз співацьких і музичних товариств” ставив перед собою мету з'єднання “українських як співацьких, так і музичних товариств,... культивування вокальної, як світської, так і церковної музики". Основними засобами досягнення мети були:

1. “Моральна і матеріальна допомога вже існуючим, а також створення нових співацьких і музичних товариств, кружків;

2. Заснування музичної школи;

3. Організація співацьких і музичних з'їздів, спільних прилюдних виступів;

4. Утримування музичної бібліотеки;

5. Розписування конкурсів на найкращий як вокальний, так інструментальні твори і їх преміювання;

6. Видавництво часописі, присвяченої співу, музиці і справам товариств співацьких і музичних, а також справам “Союза" цих товариств” [2, 3].

Так від самого початку своєї діяльності товариство обрало музично-просвітницький напрям роботи. Великі надії покладали на нього галицькі композитори. Зокрема, В. Матюк і М. Копко наголошували, що “Союз...” мусить “занятись, або дати поштовх до реорганізації науки співу музики в школах, як народних так і середніх, дальше в бурсах дяківських і шкільних, щоб тим способом дати підставу розумному плеканню співу і музики серед українців" [7, 115].

Серед перших членів об'єднання були особи, які є сьогодні гордістю української історії. Це I. Біликовський, В. Садовський, А. Вахнянин, В. Шухевич, Є. Якубович, О. Бережницький, Я. Вітошинський та ін. Вони, а також багато інших композиторів, підготували підгрунтя для створення в 1903 році Вищого музичного інституту у Львові. “Засновуючи у Львові “Вищий музичний інститут” для розумного плекання музики в широкім значенні цього слова, - писав А. Вахнянин, “Союз співацьких і музичних товариств" не починає нового діла, а продовжує, правда по довгому застої, працю, за яку не один раз бралися наші предки, щоб даний нашому народові музичний талант не запропастити, а всесторонньо використати його як один із засобів до культурного розвитку України-Руси” $[1,1]$

Отже, його виникнення не було якимось відокремленим явищем, - це результат важливих досягнень на політичному, економічному та культурному полі загального процесу національнокультурного відродження, який вимагав логічного завершення і в напряму національного та музичного виховання української молоді.

Безпосередній вплив на створення Вищого музичного інституту мали і товариства "Боян", яких об’єднувала спільна мета “плекання українського співу як хорового, так і сольного, як також інструментальної музики". За даними М. Волошина, Т. Кормоша, О. Постригача, Ю. Кмата та ін., протягом 1890-1903 рр. спостерігається така динаміка розвитку музичних товариств, яка й привела до заснування першого вищого музичного навчального закладу в Західній Україні:

- 1890 р. - Львівський Боян. Перший диригент - А. Вахнянин;

- 1891 р. - Перемиський Боян. Перший диригент - М. Копко;

- 1892 р. - Бережанський Боян. Перший диригент - О. Нижанківський;

- 1895 р. - Коломийський Боян. Перший диригент - Т. Круп'як;

- 1896 р. - Станиславівський Боян. Перший диригент - I. Біликовський;

- 1899 р. - Буковинський Боян. Перший диригент - С. Воробкевич;

- 1901 р. - Тернопільський Боян. Перший диригент - С. Терлецький;

- 1901 р. - Снятинський Боян. Перший диригент - С. Шепарович;

- 1903 р. - Союз співацьких і музичних товариств. Перший диригент - А. Вахнянин.

Таким чином, виникнення “Львівського 


\section{ВНЕСОК ГАЛИЦЬКИХ КОМПОЗИТОРІВ У ЗАСНУВАННЯ 1903 РОКУ ВИЩОГО МУЗИЧНОГО ІНСТИТУТУ У ЛЬВОВІ}

Бояна”, яке стало поштовхом для заснування багатьох подібних хорів в інших містах регіону, було підготовлене всім ходом суспільнополітичного та культурного життя. Серед першопричин його появи стали професійні проблеми, пов'язані передусім з відсутністю музичного закладу для галицького населення. Адже поляки мали свої музичні товариства: "Гармонію" (1876), "Музичне товариство ім. С. Монюшка” (1878), “Лютню” (1880), “Ехо” (1887), а також "Галицьке музичне товариство", яке від 1880 р. отримало статус консерваторії. Хоча і частково до них допускали українців, проте перевага віддавалася культивуванню винятково польського музичного мистецтва. Незаперечним $є$ той факт, що заслуги галицьких композиторів у заснуванні українських музичних товариств справді вагомі.

Музичні товариства “Боян” стають музичними центрами, в яких активно працюють галицькі композитори: у Львові-А. Вахнянин, Д. Січинський, Г. Топольницький, О. Нижанківський, І. Біликовський, Ф. Колесса, С. Людкевич; у Станиславові І. Біликовський, Д. Січинський; у Перемишлі М. Копко, Д. Січинський, Й. Кишакевич; у Коломиї - Д. Січинський; у Стрию й Бережанах -О. Нижанківський; у Чернівцях - С. Воробкевич. Таким чином, майже всі музичні сили цього періоду гуртувалися навколо цих товариств.

Поява на ниві національного життя в Галичині музичного товариства, яке вперше на офіційному рівні заговорило про свій намір виступити на захист українського музичного мистецтва, була схвально прийнята як композиторами, так i громадськістю загалом. Перші загальні збори, що відбулися 2 лютого 1891 р., затвердили статут і обрали виділ (управу - І. Ф.), до якого увійшли композитори: А. Вахнянин та Д. Січинський.

Історична роль “Боянів” полягає у тому, що вони мали вирішальний вплив на створення Вищого музичного інституту у Львові, який, як відзначає Л. Мазепа, “наближався до західноєвропейських закладів, де учні загальноосвітніх шкіл і студенти вузів навчалися паралельно, засвоюючи в консерваторії лише музичну програму" [6, 27]. Це підтверджує і часопис “Діло”, який повідомляв, що між “вписаними є учні і учениці шкіл народних, виділових і середніх, академіки та молоді урядники" $[8,3]$. Проте хоч цей заклад i наближався до західноєвропейських, за змістом і формами роботи він мав виразний національний характер. Його головною метою, як зазначено у першому параграфі статуту, було “надання своїм учням ... всебічну музичну освіту”.
Першим директором інституту став А. Вахнянин, який у вересні 1903 р. оголосив набір за спеціальностями: музичної композиції; сольного співу; хорального співу; гри на фортепіано; гри на скрипці та інших оркестрових інструментах. Викладали ї такі талановиті педагоги і композитори, як А. Вахнянин (теорія та історія музики), ЯнГаль (гармонія і композиція), О. Ясеницька (фортепіано, згодом сольний і хоровий спів), Д. Шухевичівна, М. Криницька, О. Прокешівна (фортепіано), Отто Тайтш (скрипка) [3, 103-104].

Як засвідчують наукові матеріали, оплата за навчання була досить високою. Це пояснюється тим, що Вищий музичний інститут, як і українські музичні товариства, не утримував від буржуазної держави ніякої матеріальної допомоги, тому й гроші, одержані за навчання, складали основний фонд заробітної плати викладачів. Однак навіть слабка матеріально-фінансова база, недостатня кількість національних педагогічних кадрів, упереджена політика державної влади до українського населення Західної України не зупинили його подальшого розвитку. За даними М. Волошина, на першому навчальному році навчалися 62 учні [3, 104].

Вступити до цього закладу могли ті, хто вже мав певну музичну підготовку, початкову загальну освіту, засвоїв деякі навики гри на обраному інструменті. Тут, як і в інших консерваторіях того часу, “навчалися діти і дорослі; програма передбачала проходження матеріалу початкової, середньої і вищої складності” [6, 27].

Висновки. Західноукраїнські землі у другій половині XIX - на початку XX ст. перебували у важкому соціально-політичному стані. Саме ця обставина спонукала галицьких композиторів до створення музичних товариств, які своєю діяльністю розбудили в народу бажання освіти, знання, розвитку українського музичного мистецтва.

Наведений матеріал дає можливість констатувати, що музично-просвітницька діяльність галицьких композиторів, зумовлена суспільно-політичними і культурно-освітніми факторами, мала позитивний вплив на формування національних основ музичного навчання і виховання. Завдяки композиторам ідеї музично-естетичного виховання пройшли еволюційний шлях - від простого просвітництва й залучення молоді до співу до організації різних форм мистецького навчання і виховання, в основі яких домінуючою стала національна ідея.

Кінець XIX - початок XX ст. - це якісно новий період у розвитку музичної освіти Західної України. Він характеризується появою музичних 
осередків національного спрямування, зокрема, музичних товариств “Боян”, які сприяли:

- суттєвому розширенню кола національних музичних інституцій;

- залученню молоді до числа потенційних учасників процесу національно-культурного відродження та загальноукраїнського національновизвольного руху;

- консолідації української сільської, міської, учнівської та студентської молоді Західної України навколо національної ідеї, а також ідеї розвитку українського музичного мистецтва;

- формуванню розгалуженої мережі подібних музичних товариств і заснування “Вищого музичного інституту” 1903 р. у Львові.

Постійно удосконалюючи систему навчальновиховного процесу, Вищий музичний інститут став одним із провідних закладів Західної України, в якому продовжували і розпочинали свою діяльність чимало західноукраїнських композиторів. Саме в ньому формується новий тип композитора-професіонала, який згодом, ставши педагогом, значно розширить сфери музичного шкільництва.

\section{ЛІТЕРАТУРА}

1. Вахнянин А. В справі потреби заснування музичного інституту у Львові. Діло. 1903. Ч. 197. C.1-2.

2. Відозва. Діло. 1903. Ч. 121. С. 3.

3. Волошин М. Вищий музичний інститут у Львові. Ілюстрований музичний календар. Львів. 1905. С.102-104.

4. 3 Товариств. Діло. 1903. Ч. 133. С. 3.

5. Людкевич С. Кілька слів про потребу заснування українсько-руської музичної консерваторії у Львові. Діло. 1902. Ч. 239. С. 1-2.

6. Мазепа Л. Інститут ім. М. Лисенка у Львові. Музика. 1984. № 6. С. 27-28.
7. Матюк В., Шухевич В., Копко М. Відозва до співолюбивих Русинів. Дяківський глас. 1899. Ч. 8. С. $113-116$.

8. Новинки. Діло. 1903. Ч. 207. С.3.

9. Рух в руских товариствах: З'їзд Боянів. Діло.1901. Ч.146. С. 2.

\section{REFERENCES}

1. Vakhnianyn, A. (1903). V spravi potreby zasnuvannia muzychnoho instytutu u Lvovi [The need to establish a music institute in Lviv]. Work. Lviv. Part 197. pp. 1-2. [in Ukrainian].

2. Vidozva. (1903). [Request]. Work. Lviv. Part 121. p. 3. [in Ukrainian].

3. Voloshyn, M. (1905). Vyshchyi muzychnyi instytut u Lvovi [Higher Music Institute in Lviv]. Illustrated music calendar. Work. Lviv. pp. 102104. [in Ukrainian].

4. Z Tovarystv. (1903). [From societies]. Work. Lviv. Part 133. p. 3. [in Ukrainian].

5. Liudkevych, S. (1902). Kilka sliv pro potrebu zasnuvannia ukrainsko-ruskoi muzychnoi konservatorii u Lvovi. [A few words about the need to establish a Ukrainian Music Conservatory in Lviv]. Work. Lviv. Part 239. pp. 1-2. [in Ukrainian].

6. Mazepa, L. (1984). Instytut im. M. Lysenka u Lvovi [Institute named after M. Lysenko in Lviv]. Music. Work. Lviv. Part 6. pp. 27-28. [in Ukrainian].

7. Matiuk, V., Shukhevych, V. \& Kopko, M. (1899). Vidozva do spivoliubyvykh Rusyni [Appeal to the sympathetic Ruthenians]. Deacon's voice. Work. Lviv. Part 8. pp. 113-116. [in Ukrainian].

8. Novynky (1903). [News]. Work. Lviv. Part 207. p. 3. [in Ukrainian].

9. Rukh v ruskykh tovarystvakh: Zizd Boianiv. (1901). [Movement in Ukrainian societies: Congress of Boyaniv]. Work. Lviv. Part 146. p. 2. [in Ukrainian].

Стаття надійшла до редакції 12.02.2021

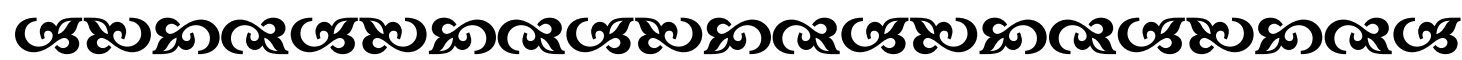

"Навряд чи взагалі є щось гідніше, яквдосконалювати свій дух, увічнювати себе в свойх творіннях і дарувати їх нащадқам".

Oлесь Тончар

украӥнський письменник, літературний қритик

"Едине, що може направити нас до благородних думок $і$ вчинқів, - це приклад великих іморально чистих особистостей".

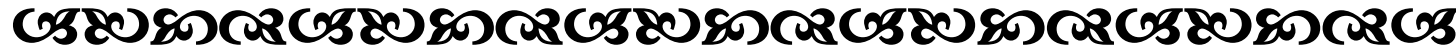

